\title{
Cutaneous leiomyomatosis in a mother and daughter ${ }^{*}$
}

\author{
Leiomiomatose cutânea em mãe e filha
}

\author{
André Lencastre ${ }^{1}$ \\ Alexandre João ${ }^{4}$ \\ Joana Cabete ${ }^{2}$ \\ Ana Fidalgo ${ }^{4}$
}

Rui Gonçalves ${ }^{3}$

DOI: http://dx.doi.org/10.1590/abd1806-4841.20132449

\begin{abstract}
A 34-year-old woman with no known medical history was evaluated for multiple painful brown nodules and papules on the anterior aspect of the trunk. She mentioned a history of similar cutaneous findings on her mother. Biopsies of three lesions revealed piloleiomyomata. Renal and adrenal ultrasound revealed an isolated simple cortical cyst, and pelvic and endovaginal ultrasound revealed two uterine myomata. The clinical diagnosis of hereditary leiomyomatosis and renal cell cancer was corroborated by the identification of a heterozygous variant on exon 5 of the fumarate hydratase gene (c.578C > T p.T193I). Identification of the tumor piloleiomyoma should alert the dermatologist to this rare genodermatosis, which is associated with an increased risk of renal cell tumors, demanding multidisciplinary follow-up, and personal and family counseling.
\end{abstract}

Keywords: Carcinoma, renal cell; Fumarate hydratase; Leiomyoma; Leiomyomatosis

Resumo: Uma mulher de 34 anos sem antecedentes patológicos conhecidos foi avaliada por apresentar múltiplos nódulos e pápulas castanhos, dolorosos, na face anterior do tronco. Referia história de achados cutâneos semelhantes na sua mãe. As biópsias de três lesões revelaram piloleiomiomas. As ecografias renal e suprarenal identificaram apenas cisto renal cortical simples, e as ecografias endovaginal e pélvica, dois miomas uterinos. O diagnóstico clínico de leiomiomatose herediária e câncer de células renais foi corroborado pela identificação de variante heterozigota no exon 5 do gene da Fumarato hidratase (c.578C >T p.T193I). O piloleimomioma é um tumor cuja identificação deve alertar o dermatologista para esta rara genodermatose, associada a um risco aumentado de tumores de células renais, exigindo seguimento multidisciplinar e aconselhamento pessoal e familiar.

Palavras-chave: Carcinoma de células renais; Fumarato hidratase; Leiomioma; Leiomiomatose

\section{INTRODUCTION}

Hereditary leiomyomatosis and renal cell cancer (HLRCC) is thought to be a rare, autossomal dominant cancer syndrome of incomplete penetrance, caused by mutations of the fumarate hydratase gene $(F H)$ located on the $1 \mathrm{q} 42.3-\mathrm{q} 43$ region. ${ }^{1,2}$

Several synonyms for HLRCC exist such as: multiple cutaneous and uterine leiomyomas 1 with or without renal cell cancer (MCUL1), and Reed's syndrome (cutaneous and uterine leiomyomatosis). ${ }^{1,3}$

HLRCC variably predisposes to: 1) cutaneous leiomyomatosis; 2) uterine leiomyomatosis (rarely with uterine leiomyosarcoma); and 3) an elevated risk of malignant renal tumors.

\section{CASE REPORT}

Patient 1, a 34-year- old woman with no previously known diseases, was evaluated for a long course of multiple papules and small nodules of brownish pink colour on the anterior aspect of the upper body, painful either spontaneously or on exposure to cold environments (Figure 1). In the past she had two lesions excised, albeit non-cognizant of their histological examination.

She denied any similar lesions on her immediate family, except for her mother who was also observed (Figure 2). The 61-year-old mother had similar lesions on her trunk and upper limbs and reported a total histerectomy for symptomatic uterine

\section{Received on 15.01.2013}

Approved by the Advisory Board and accepted for publication on 14.02.2013.

* Work performed at the Dermatology Department, Santo António dos Capuchos Hospital - Centro Hospitalar de Lisboa Central, EPE - Lisbon, Portugal. Conflict of interest: None

Financial funding: None

\footnotetext{
Degree in Medicine - Resident physician at the Dermatology/Venereology Department, Hospital de Santo António dos Capuchos - Centro Hospitalar de Lisboa Central, EPE - Lisbon, Portugal.

2 Integrated Masters Degree in Medicine - Resident physician at the Dermatology/Venereology Department, Hospital de Santo António dos Capuchos - Centro Hospitalar de Lisboa Central, EPE - Lisbon, Portugal.

Degree in Medicine - Geneticist, Hospital de Dona Estefânea, Centro Hospitalar de Lisboa Central, EPE - Lisbon, Portugal.

Degree in Medicine - Collaborating Assistant MD in Dermatology/Venereology in Department, Hospital de Santo António dos Capuchos, Centro Hospitalar de Lisboa Central, EPE - Lisbon, Portugal.
}

(C)2013 by Anais Brasileiros de Dermatologia 
myomatosis at age 38 . They both recalled a history of uterine myomatosis on the maternal grandmother.

Dermatoscopically, the lesions had a thin brownish pink pigment network (Figure 3). Renal and adrenal gland ultrasound identified a simple cortical renal cyst with $20 \mathrm{~mm}$ diameter, and pelvic and endovaginal ultrasounds two uterine myomas with 10 and $6 \mathrm{~mm}$ in patient 1. Cutaneous biopsies of three lesions from patient 1 and two from the mother revealed Piloleiomyomata (Figure 4 and 5).

A clinical diagnosis of HLRCC was made, corroborated by the identification of a heterozygous variant on exon 5 of the Fumarate Hydratase gene (c.578C > T p.T193I). lesions.

The patient decided to excise the symptomatic

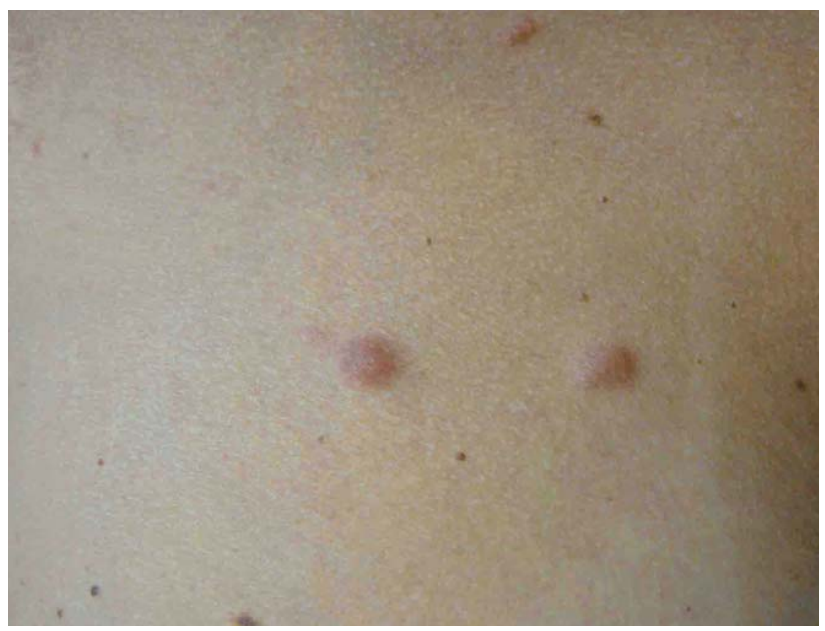

FIGURE 1: - Patient 1: Several brownish pink lesions on this patient's chest. Note recurrence of two lesions adjacent to scars belonging to past excision of lesions

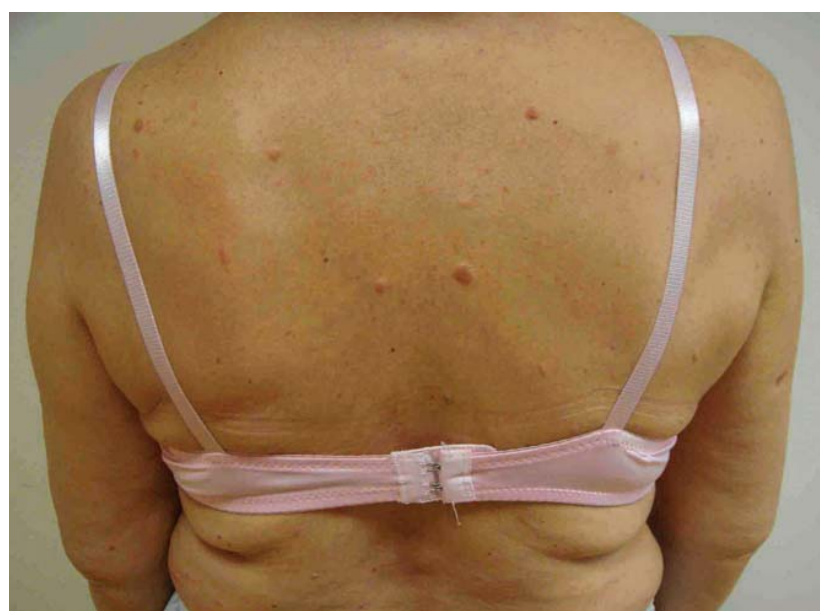

FIGURE 2: - Patient 2: Several lesions on the dorsum of the mother of the patient

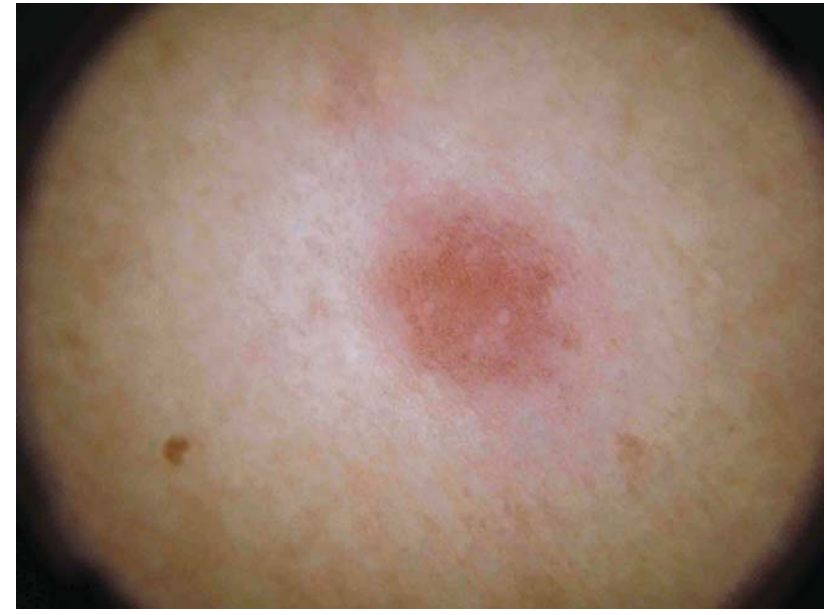

FIGURE 3: - Patient 1: Brownish pink reticular pattern, with no other local features except follicular ostia (image taken with Sony Cybershot ${ }^{\circledR}$ DSC-T77 digital camera and Dermlite ${ }^{\circledR}$ II ProHr handheld dermoscope, 3Gen, LLC; original magnification $\times 10$ )

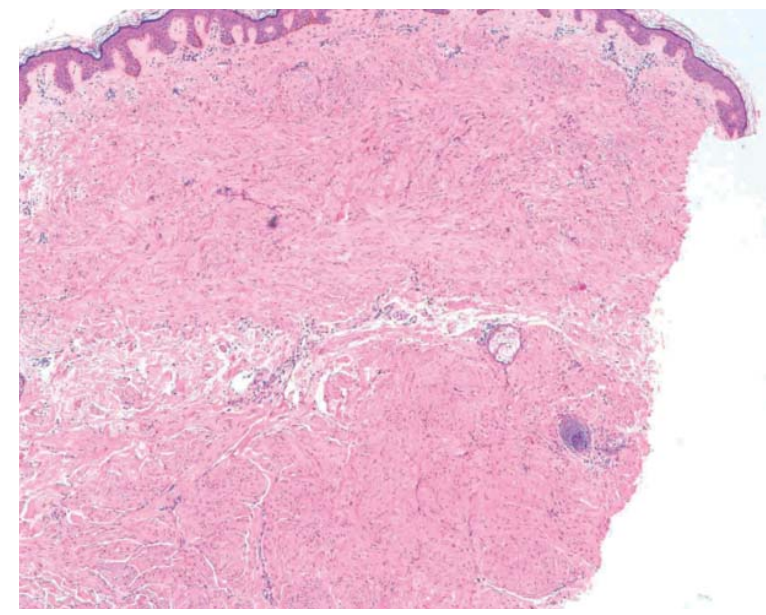

FIgURE 4: - Patient 1: Non encapsulated dermal tumor, with Grenz zone and consisting of interlaced fibers of smooth muscle cells $(\mathrm{H} \& \mathrm{E} \times 40)$

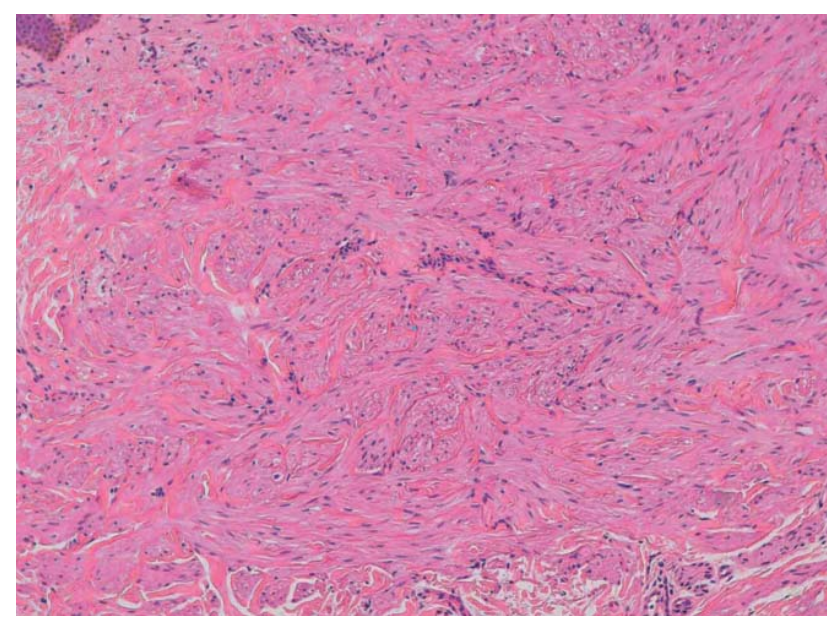

FIGURE 5: - Patient 1: Interlaced fibers of smooth muscle cells, with abundant eosinophilic cytoplasm and elongated nuclei with blunt ends $(H \& E \times 100)$ 


\section{DISCUSSION}

Although cases compatible with HLRCC already existed, the term Reed's Syndrome appeared after Reed et al recognized tumoral predisposition in a family afflicted by multiple uterine (UL) and cutaneous leiomyomas (CL). ${ }^{1}$

Multiple heterozygous mutations of the $F H$ gene were later identified, however with unknown implications in the generation of the multiple different phenotypes of this syndrome. ${ }^{4}$ In leiomyomatosis individuals, the presumed tumor suppressor activity of the fumarate hydratase is reduced. ${ }^{1,2,3}$

The most prominent phenotypical characteristic of HLRCC is the appearance of piloleiomyomas, with presumable origin in the arrector pili muscle. The number and size of these tumors can vary considerably, giving rise to cutaneous settings that vary from those that are practically unnoticeable to others that are severe and extensive. ${ }^{1,3}$ The skin-colored, red or brown papules or nodules occur in groups, scattered or both, on the limbs, trunk or face. Typically they cause pain on palpation or at low temperatures. There is a low risk for skin leiomyosarcomas. ${ }^{3}$

Dermoscopically, CLs have not been extensively described in the literature. Judging by what has been published, the findings are unspecific, varying between structureless homogeneous areas and a thin reticular pattern. ${ }^{5,6}$

The differential diagnosis should include: 1) from a clinical point of view, angiolipoma, glomus tumor and neurofibroma; and 2) histologically, smooth muscle hamartoma, dermatomyofibroma and dermatofibroma. ${ }^{7}$

ULs derived from the uterine smooth muscle cells are common benign tumors even in healthy women. In HLRCC, they are more frequent (79-100\% of cases), larger (up to $10 \mathrm{~cm}$ ), more numerous (from 1 to 20), and appear at an earlier age (average of 30 versus 40 years in sporadic cases). ${ }^{1}$ Apart from menstrual irregularity or associated pain, a growing number of infertility cases have been reported. The association with uterine leiomyosarcoma has been described as very rare. ${ }^{1,8}$

Although only $20-25 \%$ of patients apparently develop renal cell cancer (RCC), we prefer the term HLRCC in order to highlight the importance of this association. ${ }^{1,3}$ It is noteworthy that the majority of the RCC in these patients is exceptionally aggressive, with early metastasis even when smaller than $1 \mathrm{~cm} .{ }^{1}$ Papillary RCC type 2 is the most frequent subtype, followed by collecting duct RCC. When present, RCC is typically solitary and unilateral. ${ }^{1,3,8}$ Renal cysts are also more prevalent, in $36 \%$ patients versus $4.6 \%-8.3 \%$ of the general population. ${ }^{1}$

Although consensual criteria are lacking, according to those proposed by Smit et al., our patient met one major criterion (cutaneous leiomyomatosis) and one minor criterion (first-degree relative treated surgically for UL, under age 40). ${ }^{9}$ We also point to the presence of multiple small leiomyomata and a cortical renal cyst on our patient.

When the clinical and histopathological setting is suggestive, direct gene sequencing of the $\mathrm{FH}$ codifying region should be made.

Piloleiomyomata rarely demand treatment except for cosmetic purposes or for pain relief, which in most cases is tolerable. In isolated tumors surgery is frequently resorted to. For pain relief in multiple lesions, isolated or combination therapy with nitroglycerin, adrenergic receptor blockers, analgesics, antidepressants, cryotherapy or $\mathrm{CO}_{2}$ laser may be used. ${ }^{3}$

In the follow-up and treatment of UL, the same gynecologic recommendations available for the general population apply. Signs that suggest malignant transformation may be screened for in gynecology. ${ }^{3}$

Currently there are no published guidelines for the screening of RCC in HLRCC, although the main therapeutic focus of this disease should be its early detection. When a FH germline mutation is identified, the patient and relatives should be subjected to adapted screening programs. Computerized tomography (CT) at age 18 seems to us to be a reasonable course of action, followed by ultrasound, or either CT or magnetic resonance for suspicious lesions. In the first case, the surveillance interval can be annual or every 2 years. Even though RCC is rare during childhood, this possibility should be considered in families with a history of RCC at a young age, with the screening test adapted to the child's age. ${ }^{10}$

Dermatological evaluation of patients with HLRCC is mandatory. The histological confirmation of cutaneous tumors selected by their typical clinical appearance make the diagnosis easier, potentially leading to prompt cancer detection in affected patients and their families.] 


\section{REFERENCES}

1. Lehtonen HJ. Hereditary leiomyomatosis and renal cell cancer: update on clinical and molecular characteristics. Fam Cancer. 2011;10:397-411.

2. Alam NA, Bevan S, Churchman M, Barclay E, Barker K, Jaeger EE, et al. Localization of a Gene (MCUL1) for Multiple Cutaneous Leiomyomata and Uterine Fibroids to Chromossome 1q42.3-q43. Am J Hum Genet. 2001;68:1264-9.

3. Badeloe S, Frank J. Clinical and molecular genetic aspects of hereditary multiple cutaneous leiomyomatosis. Eur J Dermatol. 2009;19:545-51.

4. Tomlinson IP, Alam NA, Rowan AJ, Barclay E, Jaeger EE, Kelsell D, et al. Germline mutations in $\mathrm{FH}$ predispose to dominantly inherited uterine fibroids, skin leiomyomata and papillary renal cell cancer. Nat Genet. 2002;30:406-10.

5. Paschoal F, Rezze G. Dermoscopic findings in a patient with multiple pioleiomyomas. Dermatol Pract Concept. 2012;2:27-9.

6. Kim GW, Park HJ, Kim HS, Kim SH, Ko HC, Kim BS, et al. Giant piloleiomyoma of the forehead. Ann Dermatol. 2011;23:S144-6.

7. Suzuki H, Cavalin L, Werner B, Sato M, Brenner F. Caso para diagnóstico. Piloleiomioma múltiplo. An Bras Dermatol. 2007;82:190-2.

8. Kiuru M, Launonen V, Hietala M, Aittomäki K, Vierimaa 0, Salovaara R, et al. Familial cutaneous leiomyomatosis is a two-hit condition associated with renal cell cancer of characteristic histopathology. Am J Pathol. 2001;159:825-9.

9. Smit DL, Mensenkamp AR, Badeloe S, Breuning MH, Simon ME, van Spaendonck $\mathrm{KY}$,et al. Hereditary leiomyomatosis and renal cell cancer in families referred for fumarate hydratase germline mutation analysis. Clin Genet. 2011;79:49-59.

10. van Spaendonck-Zwarts KY, Badeloe S, Oosting SF, Hovenga S, Semmelink HJ, van Moorselaar RJ, et al. Hereditary leiomyomatosis and renal cell cancer presenting as metastatic kidney cancer at 18 years of age: implications for surveillance. Fam Cancer. 2012;11:123-9.

\author{
MAILING ADDRESS: \\ André Lencastre \\ Hospital de Santo António dos Capuchos, \\ Alameda de Santo António dos Capuchos \\ 1169-050 - Lisbon \\ Portugal \\ E-mail: lencastre.derm@gmail.com
}

How to cite this article: Lencastre A, Cabete J, Goncalves R, Joao A, Fidalgo A. Cutaneous Leiomyomatosis in a mother and daughter. An Bras Dermatol. 2013;88(6 Suppl 1):S124-7. 